\title{
PASSIVE CONTROL OF STRUCTURES FOR SEISMIC LOADS
}

\author{
Ian G BUCKLE ${ }^{1}$
}

\begin{abstract}
SUMMARY
The control of structures to improve their performance during earthquakes was first proposed more than a century ago. But it has only been in the last 25 years that structures have been successfully designed and built using earthquake protective systems. Today these systems range from simple passive devices to fully active systems. This paper focuses on passive control and reviews recent developments in the state-of-the-art.
\end{abstract}

Passive systems include tuned mass dampers, seismic (base) isolation systems, mechanical energy dissipators, and the like. Major developments in the theory, hardware, design, specification, and installation of these systems have permitted significant applications to buildings, bridges, and industrial plant. Applications are now found in almost all of the seismically active countries of the world, but principally in Italy, Japan, New Zealand and the United States. Noteworthy advantages have been demonstrated when retrofitting existing structures, and designing high-performance structures such as hospitals, emergency response facilities, defense installations, and critical bridges. Field experience in recent earthquakes has confirmed these expectations.

There are however limitations to the use of passive systems and these deserve further study and research. They include the uncertainty of response in the near field of an active fault, the nonoptimal behavior of passive systems for both small and large earthquakes, and a lack of certainty about the ultimate limit states in unexpectedly large events. As a consequence, in some jurisdictions, code provisions for passive systems are more onerous than for conventional construction, which is a strong disincentive to their use. The limited availability of design guidance in text books, code commentaries, and other design aids are further impediments to the wider use of these systems.

\section{BACKGROUND}

Structural control for seismic loads is a rapidly expanding field and the family of control systems, also known as earthquake protective systems, now embraces passive, active and hybrid systems. Applications to buildings, bridges and industrial plant have been made in many of the seismically active countries of the world. Structural control provides an alternative to conventional design methods, which are based on ductile (yielding) response. In many applications, elastic performance during large earthquake events is economically feasible and the methodology permits performance-based design criteria, now required in many modern seismic design codes, to be satisfied more readily than conventional methods. Applications to the retrofit of existing structures have been particularly attractive, especially to the upgrading of historical buildings. 
As noted above, the family of earthquake protective systems has grown to include passive, active and hybrid (semi-active) systems as shown in Figure 1. Passive systems are perhaps the best known and these include seismic (base) isolation and passive (mechanical) energy dissipation. Certainly isolation is the most developed member of the family at the present time with continuing developments in hardware, applications, design codes and retrofit manuals. But there has also been continuing growth in the passive energy dissipation field with an increasing number of different kinds of dissipation devices being developed, accompanied by technically complex applications such as those found in near-field sites.

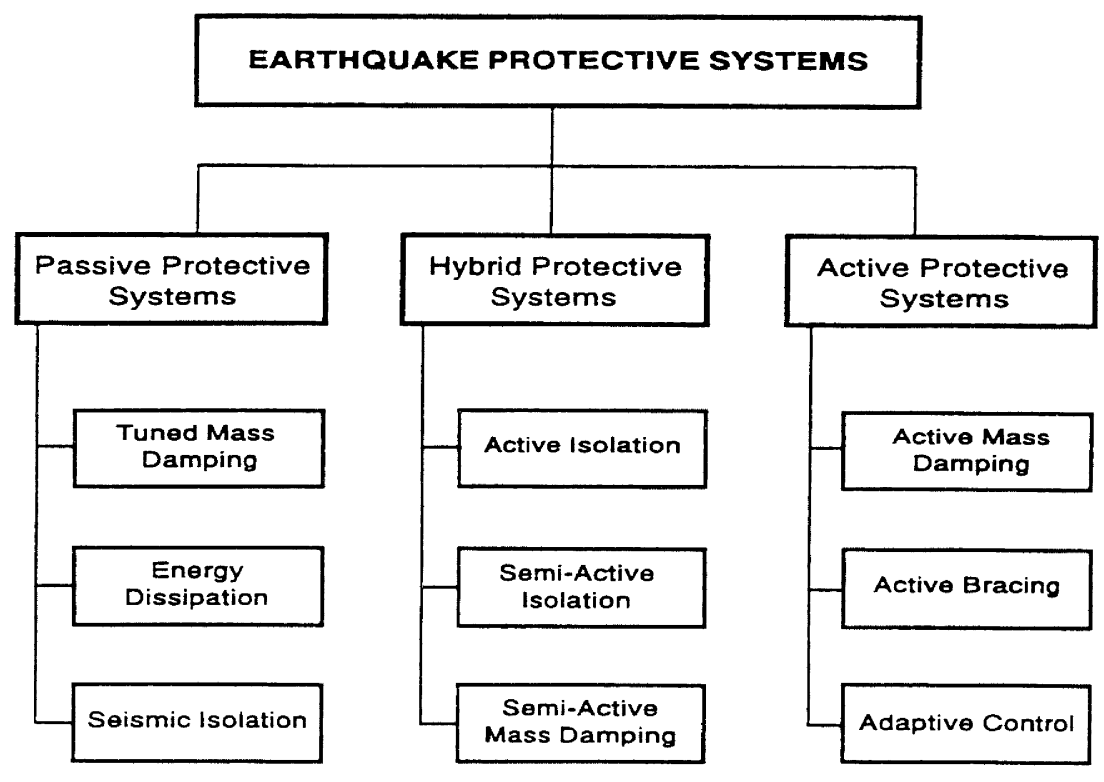

Figure 1: Family of earthquake protective systems

Seismic isolation is a design strategy that is based on the premise that it is both possible and feasible to uncouple a structure from the ground and thus protect it from damaging effects of earthquake ground motions. To achieve this result, the stiffness of the structural system is reduced by introducing flexible elements (isolators) near the base of a building, or on the pier cap, if a bridge. Additional damping may be provided in order to limit the isolator displacements to acceptable values. The concept is not new and many proposals have been made, since before the turn of the last century, for '...devices which absorb or minimize shock to buildings arising from earthquake, vibrations caused by heavy traffic or other disturbances of the earth's surface' [deMontalk, 1932]. Some of these are ingenious, others are frivolous, but all illustrate a continuing and longstanding attempt to limit the effects of large earthquakes in a uniquely different manner. One of the earliest in this regard is the patent by Jules Touaillon of San Francisco filed in the US Patent Office in February 1870. It describes an 'earthquakeproof building' which is seated on steel balls which roll inside shallow dishes. As far as can be determined, few if any of these early proposals were built, most probably due to their impracticality and a lack of enthusiasm from the building officials of the day.

The modern era of isolation is considered by many to have begun in the mid-seventies in New Zealand with the construction of a stepping, high-level, rail bridge across the South Rangitikei River in the central region of the North Island. The element of flexibility is provided by structural separation of the columns at the pile cap enabling a stepping motion to occur (ie lateral rocking). The displacements are controlled by steel torsion-bar energy dissipators, also located at the pile cap. This landmark development was followed in 1982 with the William Clayton building in Wellington, which used lead-filled elastomeric bearings as the isolator and damper. Almost a quarter-century later, there appear to be more than 400 seismically isolated buildings, bridges, and items of industrial plant worldwide. The majority of these applications may be found in Italy, Japan, New Zealand and the United States. Some of this activity is reported by Buckle and Mayes [1990] and in the Proceedings of the World Conferences on Earthquake Engineering in Madrid (1992) and Acapulco (1996).

Common isolation systems in use today include elastomeric and sliding bearings with and without dampers or damping mechanisms. For example, elastomeric bearings may be fabricated from a high damping rubber compound or contain a lead core. Sliding bearings dissipate energy by friction, and may use a separate 
mechanism to provide a self-centering capability or employ a curved sliding surface that may be spherical, conical, or of varying curvature. Combinations of elastomeric and sliding bearings are also used, together with roller-based systems, but less frequently. The rollers may be cylinders or balls sandwiched between flat or curved plates. Variations on this theme usually involve added damping mechanisms such as metallic and hydraulic dampers.

Research and development on passive energy dissipation systems began about the same time as modern isolation, motivated at the time, by a need to control isolator displacements. Thus the early passive energy dissipators were used in association with elastomeric and sliding isolators and were principally of the metallic type (steel cones and tapered plates). Today the state-of-the-art has evolved to the point where they are used as an alternate to isolation and may be incorporated within the structural frame of a building or between the superand substructures of a bridge. Their function is to dissipate energy during an earthquake and reduce the demand on the structural frame. However, these dampers will also add strength and stiffness to the frame and if these contributions are large compared to the frame itself, they may offset the advantages generated by the increase in damping.

Nevertheless, significant reductions in damage to the frame (ductile yielding) are possible but not to the same extent as that provided by an isolation system. However, unlike isolation, passive energy dissipators also reduce wind response and are applicable to a wider range of structures, especially those sensitive to long period ground motions. In retrofit situations they may also be less intrusive than a comparable isolation system.

Passive energy dissipators may be simply classified as hysteretic or viscoelastic [Constantinou, Soong, and Dargush, 1998]. Hysteretic dissipators include the yielding of metals due to flexure, shear, torsion, or extrusion (metallic dampers) and sliding (friction dampers). They are all essentially displacement-dependent devices. Viscoelastic systems include viscoelastic solids, fluid orificing (fluid dampers), and viscoelastic fluids. They are essentially velocity-dependent devices (viscous in nature) and many are also frequency dependent. Some passive energy dissipators are modifications of the above set and may include elastic springs or pressurized cylinders to develop pre-load and re-centering capabilities.

In a subset of passive energy dissipators are tuned mass dampers (TMD) and tuned liquid dampers (TLD). Used principally for controlling wind vibrations in elastic structures these vibration absorbers dampen motion by transferring kinetic energy between various modes of vibration. Tuned to a particular dominant mode, such a device may enhance the damping in tall structures by about $5 \%$, which is usually sufficient for improved comfort levels during wind storms. Seismic applications are however rare and these devices are not discussed further in this paper. It is perhaps worth noting that TMDs are frequently used during the construction of tall slender structures, such as the towers of suspension bridges, for protection against wind loads. The world's longest suspension bridge, the Akashi-Kaikyo bridge near Kobe, Japan, was under construction at the time of the Great Hanshin Earthquake in 1995. The epicenter was on the Nojima fault which passes between the two towers at a shallow angle. Although at their full height at the time of the earthquake, the towers were not damaged, possibly due (in part) to the presence of the TMDs.

Common passive energy dissipators in use today include hysteretic flexural, torsional and extrusion devices, friction dampers, and viscoelastic solid and fluid dampers. In 1998, the number of applications in North America (Mexico, US and Canada) was of the order of 80 [Constantinou, Soong and Dargush, 1998]. Of these about one-half were viscoelastic fluid dampers, one-third were friction dampers, and the remaining one-sixth included hysteretic, viscoelastic solid, and tuned mass dampers.

\section{SOME NOTABLE APPLICATIONS}

In a paper such as this, it is no longer feasible to make a comprehensive review of world-wide applications of earthquake protective systems. The growth of the field and the number of such applications precludes such a review [Naeim and Kelly, 1999]. Instead, Table 1 summarizes a selection of building applications in the United States and four recent notable applications are described in the following sections. 
Table 1: Summary of US seismic isolation rehabilitation projects [FEMA, 1997b]

\begin{tabular}{|c|c|c|c|c|c|}
\hline \multicolumn{3}{|c|}{ Building/Project Information } & \multicolumn{3}{|c|}{ Structural Information } \\
\hline $\begin{array}{l}\text { Name } \\
\text { (Location) }\end{array}$ & Status & $\begin{array}{l}\text { Size in } \\
\text { Sq. Ft. }\end{array}$ & $\begin{array}{l}\text { Isolation } \\
\text { System }\end{array}$ & $\begin{array}{l}\text { Original } \\
\text { Structure }\end{array}$ & $\begin{array}{l}\text { New } \\
\text { Structure }\end{array}$ \\
\hline $\begin{array}{l}\text { Salt Lake City and } \\
\text { County Building } \\
\text { (Salt Lake City, UT) }\end{array}$ & $\begin{array}{l}\text { Complete } \\
(1988)\end{array}$ & 170,000 & $\begin{array}{l}447 \text { Isolators } \\
\text { (208 LRB } \\
+239 \text { RB } \\
+ \text { PTFE) }\end{array}$ & $\begin{array}{l}18945 \text {-story URM } \\
\text { bearing wall w/clock } \\
\text { tower ( } 240^{\prime} \text { total } \\
\text { height) }\end{array}$ & $\begin{array}{l}\text { Steel braced frame } \\
\text { (clock tower only) }\end{array}$ \\
\hline $\begin{array}{l}\text { Rockwell Building } \\
\text { (Seal Beach, CA) }\end{array}$ & $\begin{array}{l}\text { Complete } \\
(1991)\end{array}$ & 300,000 & $\begin{array}{l}78+\text { (solators } \\
\text { (52 LRB } \\
+26 \text { RB } \\
+ \text { PTFE) }\end{array}$ & $\begin{array}{l}1967 \text { 8-story } \\
\text { RC moment frame }\end{array}$ & $\begin{array}{l}\text { RC moment frame at } \\
\text { perimeter, floors } 1-6\end{array}$ \\
\hline $\begin{array}{l}\text { Hawley Apartments } \\
\text { (San Francisco, CA) }\end{array}$ & $\begin{array}{l}\text { Complete } \\
(1991)\end{array}$ & 20,000 & $\begin{array}{l}31 \text { Isolators } \\
\text { (FPS) }\end{array}$ & $\begin{array}{l}19204 \text {-story wood } \\
\text { bearing wall }\end{array}$ & $\begin{array}{l}\text { Steel moment frame } \\
\text { at first floor }\end{array}$ \\
\hline $\begin{array}{l}\text { Mackay School of } \\
\text { Mines } \\
\text { (Reno, NV) }\end{array}$ & $\begin{array}{l}\text { Complete } \\
(1993)\end{array}$ & 50,000 & $\begin{array}{l}106 \text { lsolators } \\
\text { (64 HDR } \\
+42 \text { PTFE) }\end{array}$ & $\begin{array}{l}1908 \text { 3-story URM } \\
\text { bearing wall }\end{array}$ & $\begin{array}{l}\text { Floor ties/wall } \\
\text { anchors (new } \\
\text { basement) }\end{array}$ \\
\hline $\begin{array}{l}\text { Campbell Hall, } \\
\text { Western Oregon } \\
\text { State College } \\
\text { (Monmouth, OR) }\end{array}$ & $\begin{array}{l}\text { Complete } \\
\text { (1994) }\end{array}$ & & $\begin{array}{l}42+\text { Isolators } \\
\text { (26 LRB } \\
+16 \text { RB } \\
+ \text { PTFE) }\end{array}$ & $\begin{array}{l}1872-1898 \\
\text { 3-story URM bearing } \\
\text { wall }\end{array}$ & \\
\hline $\begin{array}{l}\text { Oakland City Hall } \\
\text { (Oakland, CA) }\end{array}$ & $\begin{array}{l}\text { Complete } \\
(1995)\end{array}$ & 153,000 & $\begin{array}{l}126 \text { Isolators } \\
\text { (42 LRB } \\
+69 \text { RB } \\
+15 \text { PTFE) }\end{array}$ & $\begin{array}{l}1914 \\
18-\text { story steel frame/ } \\
\text { URM in-fill w/clock } \\
\text { tower ( } 324^{\prime} \text { total } \\
\text { height) }\end{array}$ & $\begin{array}{l}\text { RC shear walls at } \\
\text { cores, steel braced } \\
\text { frame at clock tower }\end{array}$ \\
\hline $\begin{array}{l}\text { U.S. Court of Appeals } \\
\text { (San Francisco, CA) }\end{array}$ & $\begin{array}{l}\text { Complete } \\
\text { (1995) }\end{array}$ & 350,000 & $\begin{array}{l}256 \text { isolators } \\
\text { (FPS) }\end{array}$ & $\begin{array}{l}1905 \text { 4-story steel } \\
\text { frame/URM in-fill with } \\
1933 \text { addition }\end{array}$ & RC shear walls \\
\hline $\begin{array}{l}\text { Long Beach Veterans } \\
\text { Admin. Hospital } \\
\text { (Long Beach, CA) }\end{array}$ & $\begin{array}{l}\text { Complete } \\
(1995)\end{array}$ & 350,000 & $\begin{array}{l}156 \text { Isolators } \\
\text { (110 LRB } \\
+18 \text { RB } \\
+30 \text { PTFE) }\end{array}$ & $\begin{array}{l}1967 \text { 12-story RC } \\
\text { perforated shear wall }\end{array}$ & $\begin{array}{l}\text { Basement columns } \\
\text { strengthened }\end{array}$ \\
\hline $\begin{array}{l}\text { Building S-12 Hughes } \\
\text { (E) Segundo, CA) }\end{array}$ & $\begin{array}{l}\text { Complete } \\
\text { (1995) }\end{array}$ & 240,000 & $\begin{array}{l}45+\text { Isolators } \\
\text { (24 LRB } \\
+21 \text { RB } \\
+ \text { PTFE) }\end{array}$ & $\begin{array}{l}1960 \text { s } 12 \text {-story RC } \\
\text { shear wall/frame } \\
\text { building }\end{array}$ & $\begin{array}{l}\text { First floor and } \\
\text { substructure } \\
\text { strengthened }\end{array}$ \\
\hline $\begin{array}{l}\text { Kerckhoff Hall, } \\
\text { Univ. of California, Los } \\
\text { Angeles } \\
\text { (Westwood, CA) }\end{array}$ & $\begin{array}{l}\text { Complete } \\
(1996)\end{array}$ & 92,000 & $\begin{array}{l}126+\text { Isolators } \\
\text { (33 LRB } \\
+93 \text { RB } \\
+ \text { PTFE) }\end{array}$ & $\begin{array}{l}\text { 6-story } R C \text { and brick } \\
\text { wall structure }\end{array}$ & $\begin{array}{l}\text { First floor and } \\
\text { substructure } \\
\text { strengthened }\end{array}$ \\
\hline $\begin{array}{l}\text { San Francisco } \\
\text { City Hall } \\
\text { (San Francisco, CA) }\end{array}$ & $\begin{array}{l}\text { Complete } \\
(1997)\end{array}$ & 500,000 & $\begin{array}{l}591 \text { Isolators } \\
\text { (530 LAB } \\
+61 \text { PTFE) }\end{array}$ & $\begin{array}{l}19125 \text {-story steel } \\
\text { frame/URM in-fill with } \\
\text { dome ( } 300^{\prime} \text { total } \\
\text { height) }\end{array}$ & $\begin{array}{l}\text { Steel braced frame in } \\
\text { dome and } \\
\text { RC shear walls at } \\
\text { lower floors }\end{array}$ \\
\hline
\end{tabular}

LRB: Lead-rubber bearing isolators

RB: Rubber bearing isolators

PTFE: Sliding polytetra fluoroethylene isolators

FPS: Friction pendulum system isolators

HDR: High damping rubber bearing isolators

\subsection{New Zealand Parliament House and Library}

The seismic retrofit of this historic pair of buildings in Wellington, is another in the series of isolation retrofits for seismically weak but historically important structures around the world. Built in 1899 and 1922 respectively, the Library and Parliament House are both constructed from unreinforced masonry, principally stone (granite) and brick (Figure 2). Seismic isolation was chosen over conventional strengthening techniques despite a slight premium in cost (about 3\%). The preservation of the historic fabric of the buildings was a deciding factor in this decision, together with improved seismic performance at high levels of ground shaking. The site is on rock, close to the original Wellington shoreline, within a kilometer (half-mile) of the Wellington fault, and $5 \mathrm{~km}(3 \mathrm{mi})$ from the parallel Wairarapa fault. Both faults represent the boundary between the Pacific and Indian plates. Seismic risk studies estimated peak ground accelerations from the Maximum Probable Event ( $\mathrm{M}=6.5$ on the Wairarapa fault) to be $0.5 \mathrm{~g}$, and from the Maximum Credible Event $(\mathrm{M}=7.0$ to 7.5 on the Wellington fault) to be $0.85 \mathrm{~g}$. The isolation system comprises 145 lead-rubber bearings, 230 high-damping rubber bearings, and 42 sliders. The isolated period is estimated to be 2.5 seconds and the isolator design displacement, at this period, is calculated to be $385 \mathrm{~mm}$ (15.2 in). 
Installation of the isolators required strengthening of basement walls and columns, and the provision of floor diaphragms. As shown in Figure 3, load transfer to the isolators was provided by sandwich and needle beams that were similar to those used for the isolation retrofit of the Salt Lake City Building [Buckle and Mayes, 1990]. The total cost for the restoration and seismic retrofit of these two buildings was approximately US\$90 million. The project was completed in 1995.

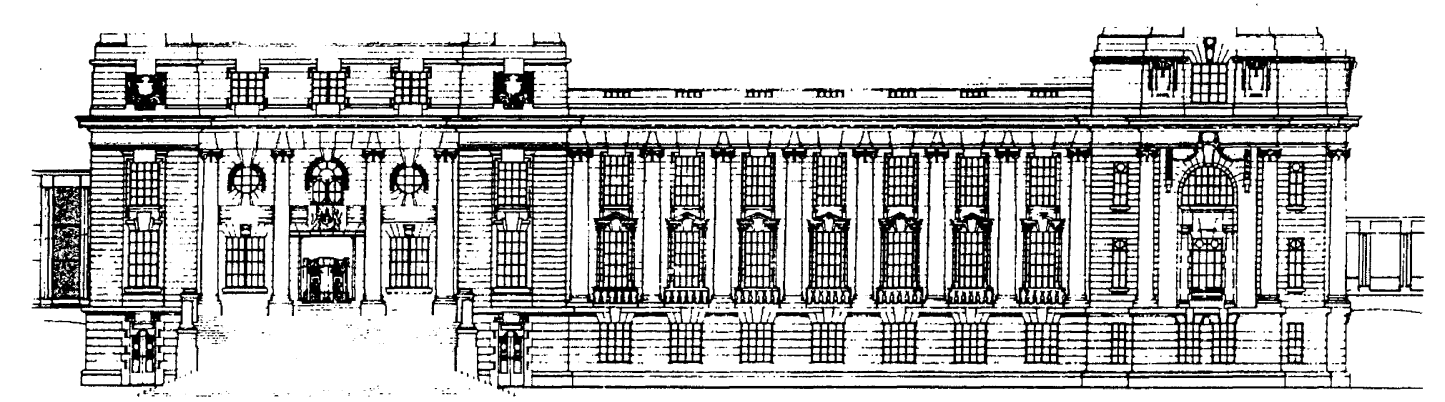

Figure 2a: New Zealand Parliament House

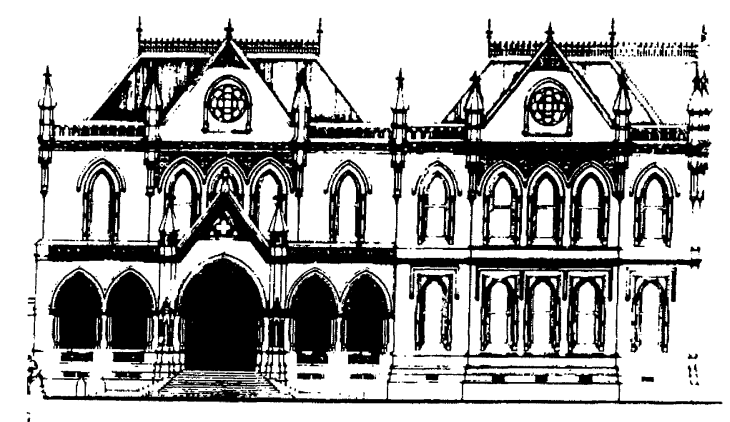

Figure 2b: New Zealand Parliament Library

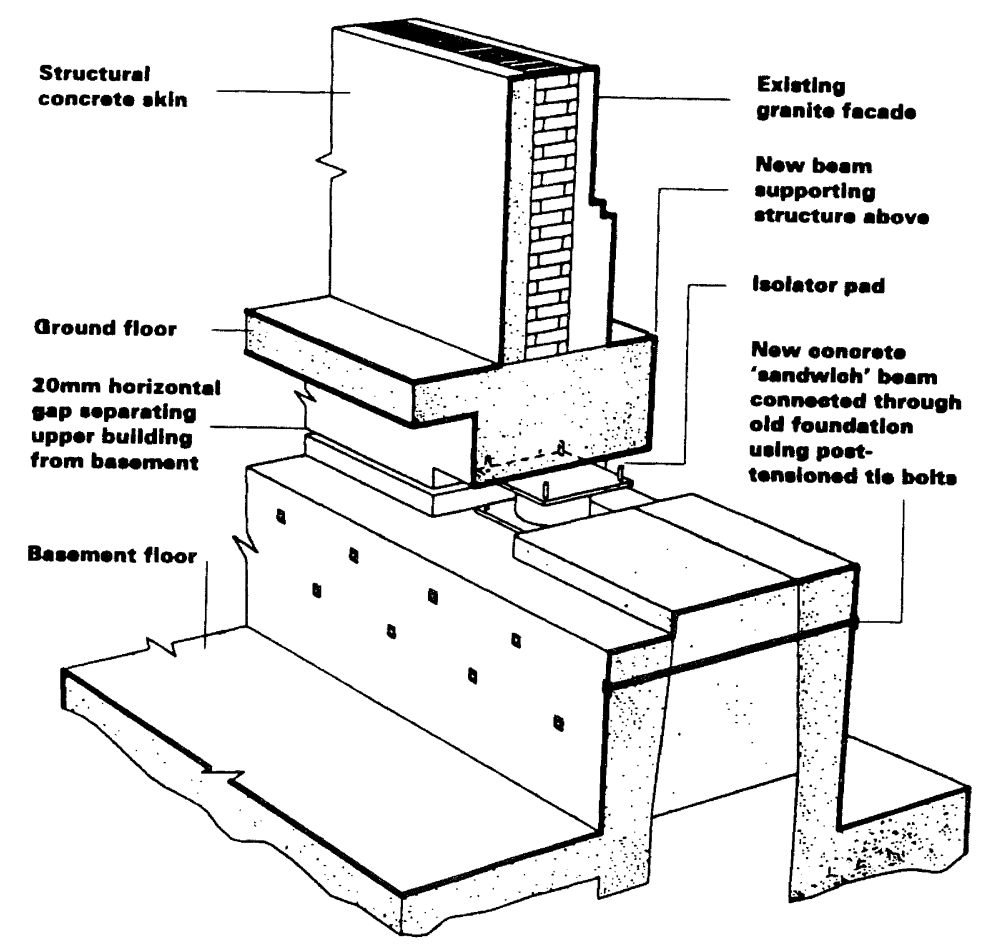

Figure 3: Strengthening of foundation walls below NZ Parliament House and location of isolators 


\subsection{Arrowhead Regional Medical Center, California}

Formerly known as the San Bernardino Medical Center, this US $\$ 450$ million facility is a new general hospital for San Bernardino County in Southern California (Figure 4). It is in fact a campus of five, separate, steelbraced and moment-resisting-frame buildings that share a common raft foundation for load distribution to the isolators below the lowest floor level. About $86,400 \mathrm{~m}^{2}\left(930,000 \mathrm{ft}^{2}\right)$ of floor space is protected in this manner making it one of the largest isolated buildings in the world. In addition it was one of the first isolated structures to use both hysteretic and viscoelastic dampers in parallel. The site is in the near field of the San Andreas and San Jacinto faults and the corresponding peak ground motion for the design basis earthquake was $0.70 \mathrm{~g}$, with potential for extreme velocity pulses. Viscoelastic dampers were included to limit peak isolator displacements to less than $\pm 600 \mathrm{~mm}( \pm 24 \mathrm{in})$. The isolation system therefore comprised 392 high-damping rubber isolators and 184 passive fluid viscous dampers. Figures 5 and 6 show the location and dimensions of these dampers. Each is capable of delivering $1420 \mathrm{kN}(320 \mathrm{kip})$ of force at a velocity of $1.5 \mathrm{~m} / \mathrm{sec}(60 \mathrm{in} / \mathrm{sec})$. They have a stroke of $\pm 600 \mathrm{~mm}( \pm 24 \mathrm{in})$ and can dissipate $2100 \mathrm{~kW}(2800 \mathrm{hp})$ of energy.

\subsection{US Court of Appeals, San Francisco}

This building was constructed in 1905 and modified in 1933 to give it a rectangular footprint with a central

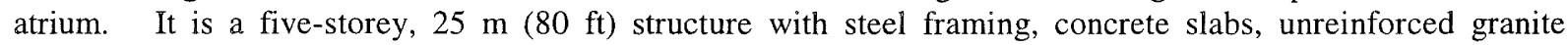
masonry exterior walls and hollow clay tile interior partitions. The building is on the National Register of Historic Places and was damaged in both the San Francisco (1906) and Loma Prieta earthquakes (1989). The isolation system chosen for the building consists of 256 friction pendulum (FPS) bearings which consist of an articulated slider, faced with a composite PTFE material, and a concave stainless steel spherical surface. Each isolator has a radius of $1880 \mathrm{~mm}$ (74 in) corresponding to an isolation period of 2.75 seconds. The design coefficient of friction was $0.07(\max )$ for sliding velocities greater than $50 \mathrm{~mm} / \mathrm{sec}(2.0 \mathrm{in} / \mathrm{sec})$ and $0.045(\mathrm{~min})$ at very low sliding velocities. A typical installation is shown in Figure 7.

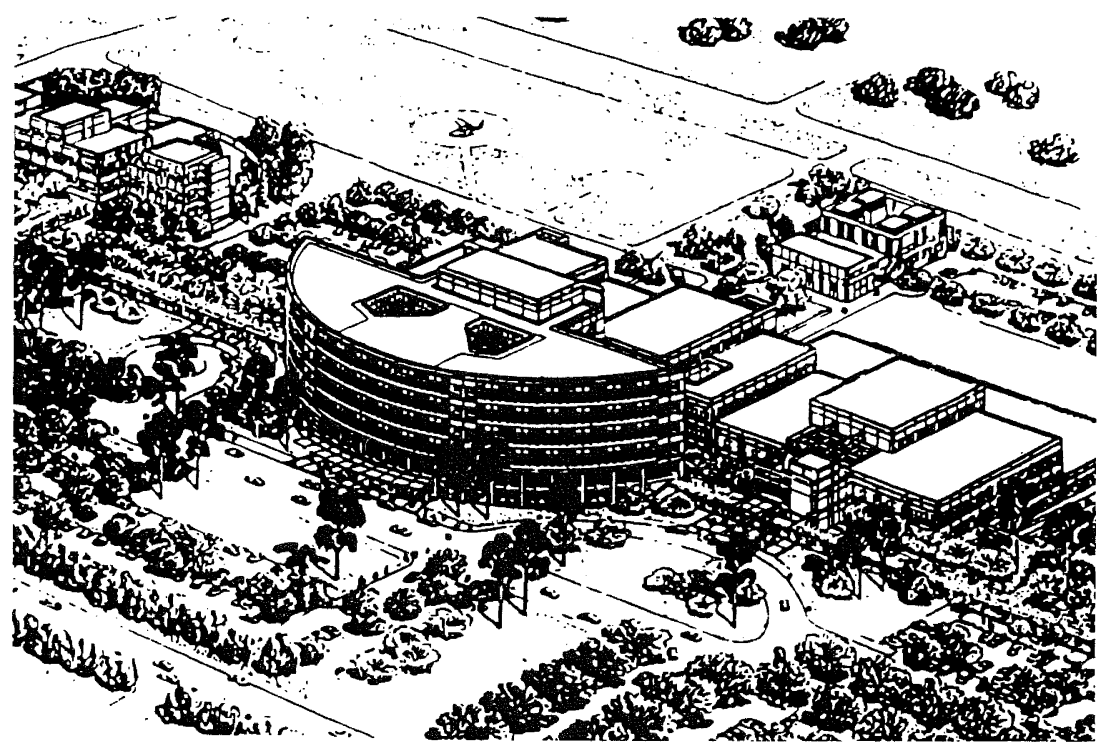

Figure 4: Arrowhead Regional Medical Center

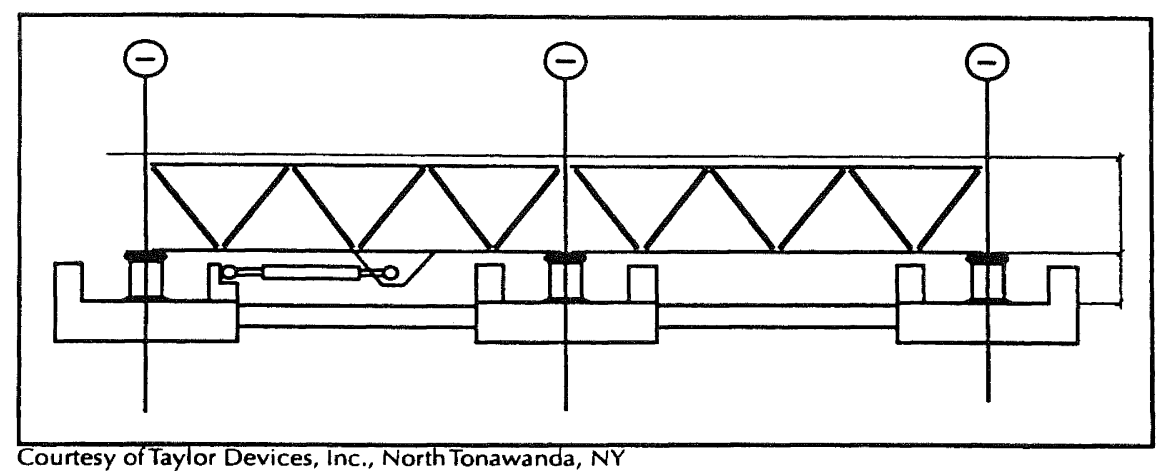

Figure 5: Location of viscous fluid dampers and seismic isolators below the Arrowhead facility 


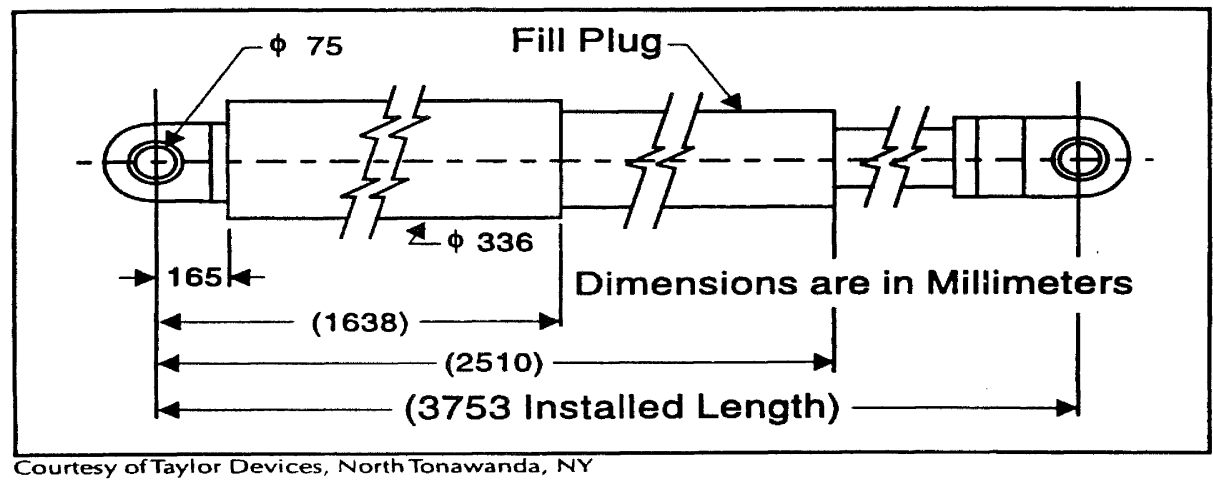

Figure 6: Dimensions of viscous fluid damper for the Arrowhead Facility

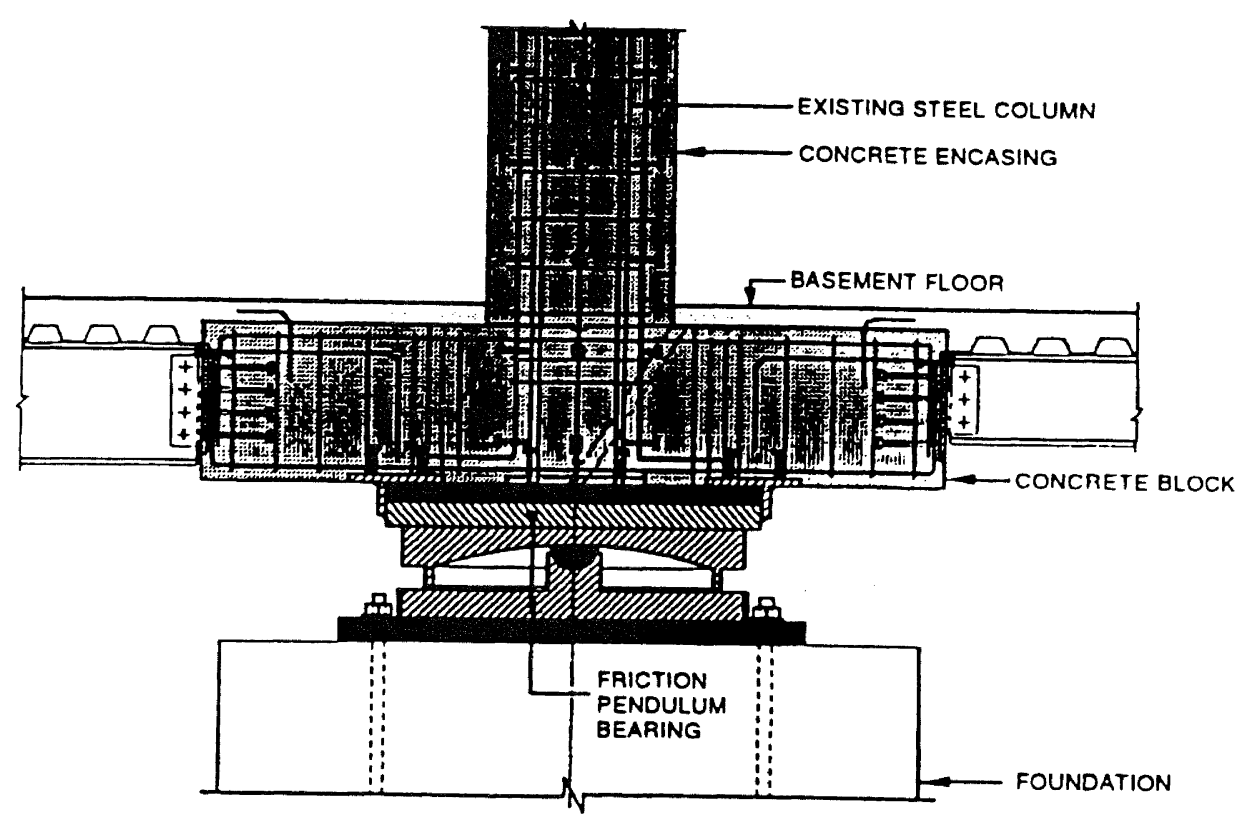

Figure 7: Installation detail for friction pendulum isolators, Court of Appeals, San Francisco [Amin, Mokha, and Fatehi, 1993]

\subsection{Building 116, Naval Supply Facility, San Diego}

This project is the first known application of viscoelastic energy dissipators to the seismic retrofit of an existing building [Constantinou, Soong and Dargush, 1998]. Located in San Diego, the building is a 3-storey nonductile reinforced concrete structure with $200 \mathrm{~mm}$ (8 in) thick perimeter shear walls as the lateral load resisting system. Figure 8 shows the principal dimensions of the building where it is seen that the floors are flat slabs with column capitals. The foundations are reinforced concrete footings under the exterior walls and a $150 \mathrm{~mm}(6$ in) slab-on-grade elsewhere. At risk under even a moderate earthquake, the retrofit strategy called for the use of 64 viscoelastic shear dampers to reduce interstory drifts to acceptable levels. Four dampers have been mounted on each of $16 \mathrm{~K}$-braces in the first and second floors of the building (Figure 9).

\section{SOME NOTABLE DEVELOPMENTS}

\subsection{Stability of Elastomeric Isolators}

When used as seismic isolators, elastomeric bearings may be subjected to large axial loads at high shear strains and their stability under these conditions is of concern. As a result, conservative estimates of axial load capacity are inherent in most codes and design guides, leading in many instances to uneconomical bearing designs. For 
example, the axial load capacity is assumed to be directly proportional to the 'overlap' area between the uppermost and lowest shim in a bearing and at shear displacements approaching the width (or diameter) of a bearing, this area, and thus the axial load capacity, becomes negligible. Research by Koh and Kelly [1989], Buckle and Liu [1993] and more recently by Nagarajaiah and Ferrell [1999], suggest that these conservative design rules may be relaxed. Nagarajaiah and Ferrell have extended the Koh-Kelly small-displacement model to include large displacements, large rotations, and rubber nonlinearities. They then show that, whereas both the critical load and the horizontal stiffness decrease with increasing shear displacement, neither become zero at a displacement equal to the width of the bearing. This result confirms experimental observations by Buckle and Liu [1993]. Instead substantial capacity remains which varies

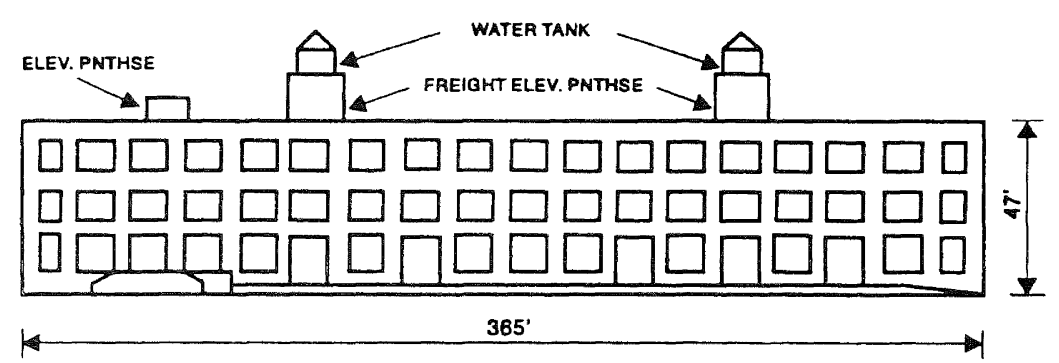

(a) Front Elovation

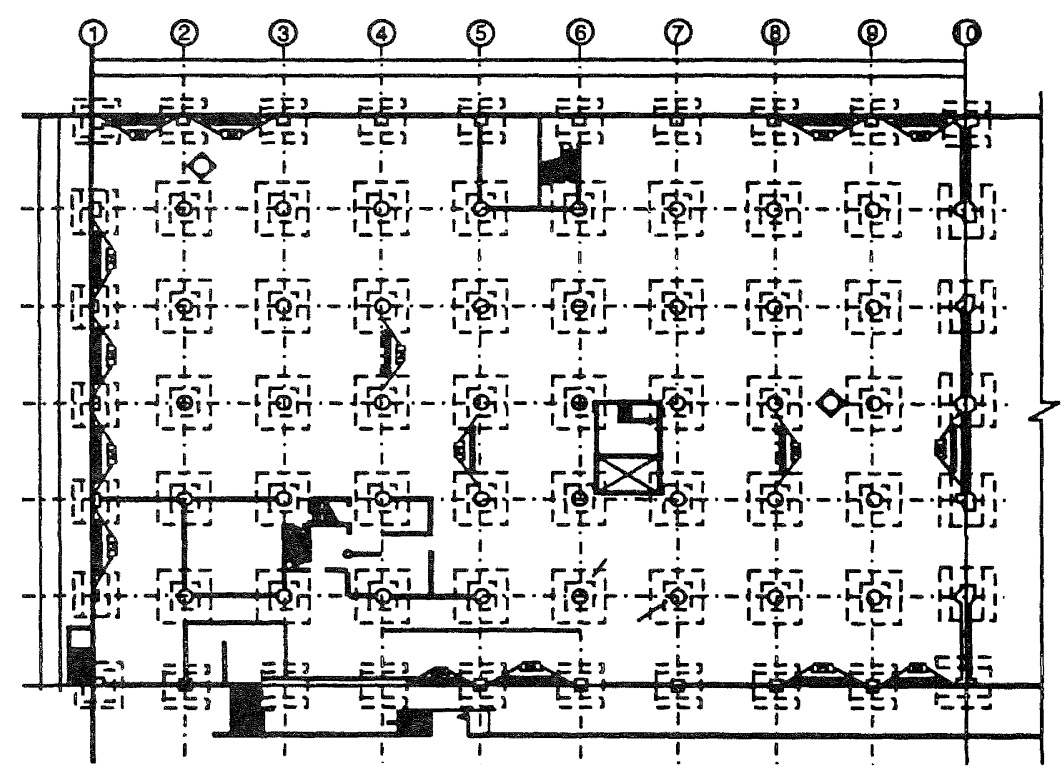

(b) Floor Plan Showing Damper Locations (FIrst Floor, North Half)

Figure 8: Elevation and plan, Building 116, Naval Supply Facility, San Diego

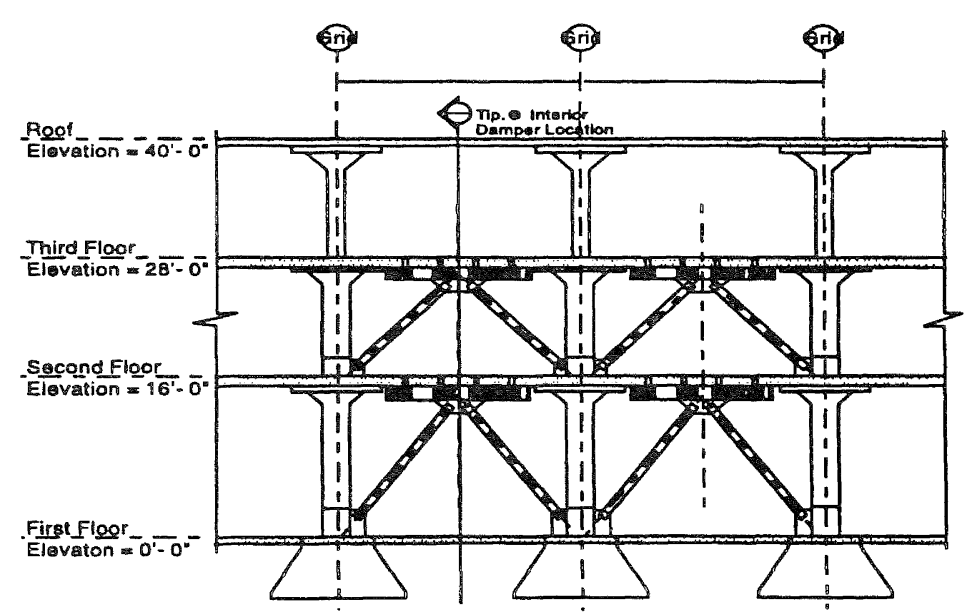

Figure 9: Location of viscoelastic dampers in first and second floors, Building 116 
with shape factor. This capacity may be as high as 30 to $50 \%$ of the critical load of the undeformed bearing for shape factors less than or equal to 5 . Results for shape factors above 5 are under review. Figure 10 shows the comparison between theoretical results and experimental observations [Buckle and Liu, 1993] for two bearings of low shape factor. In both cases the bearing width is $125 \mathrm{~mm}(5 \mathrm{in})$ and it will be seen that whereas the code provision implies a zero critical load at this displacement, Nagarajaiah's work indicates a substantial reserve in strength at this point. Relaxation of code restrictions on axial load capacity are thus indicated, which in turn will lead to more cost-effective elastomeric isolator designs.

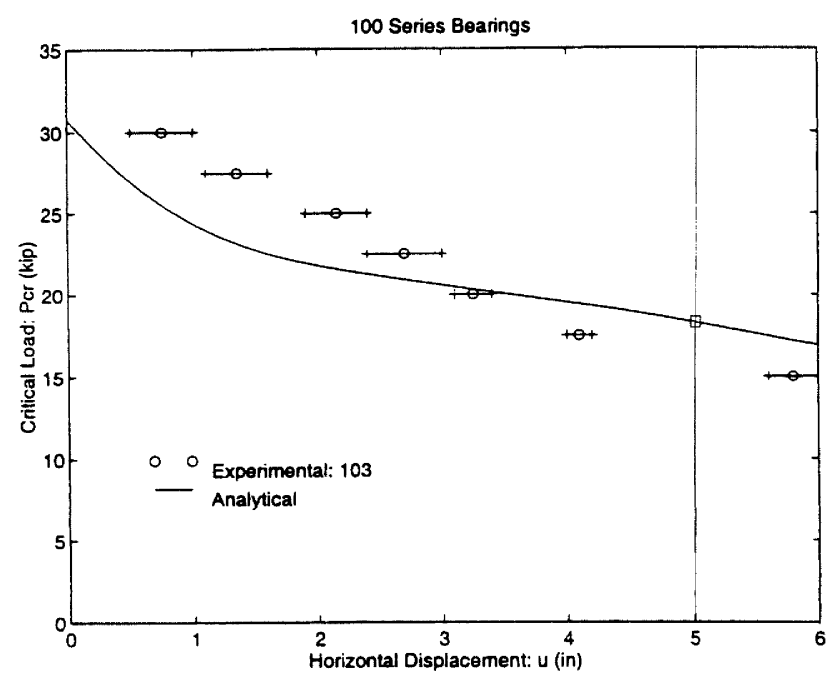

Figure 10a: Variation of critical axial load with horizontal displacement for 100 series bearing; width $=125 \mathrm{~mm}(5 \mathrm{in})$, shape factor $=1.67$ [Nagarajaiah and Ferrell, 1999]

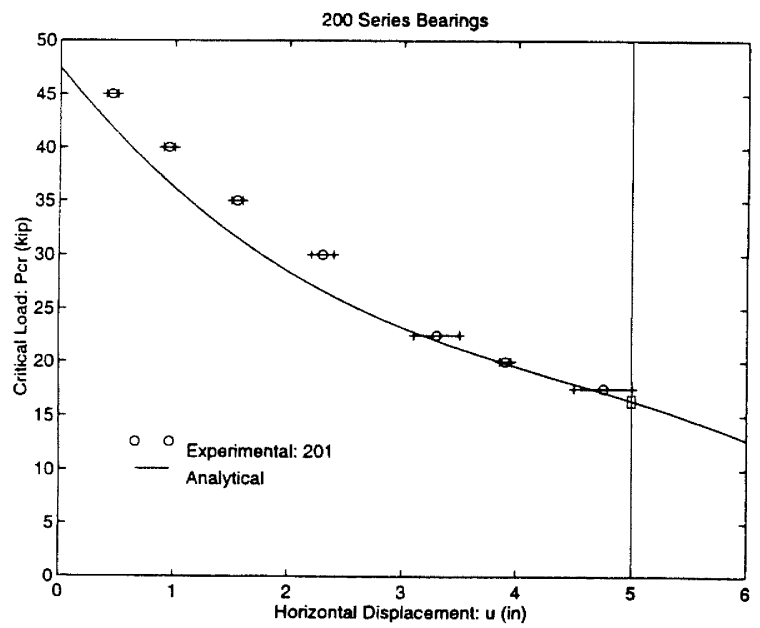

Figure 10a: Variation of critical axial load with horizontal displacement for 200 series bearing; width $=125 \mathrm{~mm}$ ( 5 in), shape factor $=2.5$ [Nagarajaiah and Ferrell, 1999]

\subsection{Near-field Ground Motions, Damping and Optimal Design of Passive Systems}

As noted above, the Arrowhead Regional Medical Center is in a near-field site and additional damping has been added at the isolation interface to limit otherwise excessive displacements to acceptable values. Whereas the isolator displacements and structure base shear are reduced by this strategy, the impact of this added damping on interstory drifts and floor accelerations in the superstructure is not so clear. Kelly [1999] has recently studied this problem and shown that both drift and floor accelerations increase with added damping. Kelly's model is linear but includes the modal coupling terms caused by high levels of damping in the isolation system. $\mathrm{He}$ demonstrates that the contribution of these coupling terms dominates superstructure response with adverse 
consequences. Kelly challenges that at high equivalent viscous damping ratios of around $50 \%$ (as calculated by Kelly for the Arrowhead facility) 'the basic concept of base isolation cannot hold.' Similar questions have been raised by Lee et al [1999] in their work on supplemental damping in framed structures. However Hall and Ryan [to appear] dispute Kelly's findings and in believe that the equivalent viscous damping in the Arrowhead facility is more like $30 \%$. They also calculate smaller drifts than those reported by Kelly. Resolution of this issue is exceptionally important for the future of isolated buildings in near-field sites.

A consequence of designing isolators for very large and very rare events is the possibility that in a more probable, lower level earthquake, (one more likely to occur in the life of the structure), the isolation system will not operate. It will be too stiff and too heavily damped to be useful [Kelly, 1999]. The result will be floor accelerations possibly of a size to damage non-structural elements and equipment, and while not likely to be a life-safety issue, places immediate functionality at risk. This topic also deserves immediate attention.

\subsection{New Hardware}

Just as it is difficult to make a detailed review of applications in a paper such as this, it is also difficult to make a comprehensive review of hardware developments. The growth of the field and the number of new devices now appearing in the marketplace precludes such a review. The reader is therefore referred to summaries by Olariu [1995], Housner et al [1997], Constantinou, Soong and Dargush [1998], and Naeim and Kelly [1999]. Examples of new developments in the passive control field include an FPS isolator with a reduced footprint, a concrete filled tube (structural brace) that is ductile in both tension and compression, and an omnidirectional hysteretic ball damper that does not degrade [Robinson, 1999].

\subsection{Quality Assurance and the HITEC Evaluation of Isolation Systems}

In response to the rapid growth in hardware for passive control, the California Department of Transportation (Caltrans), with sponsorship from the Federal Highway Administration (FHWA), asked the Highway Innovative Technology Evaluation Center (HITEC) of the Civil Engineering Research Foundation (CERF), to evaluate eight of the isolation systems being used, or proposed for use, in bridges in the US. The eight systems tested in 1996 and 1997 were [Ghasemi and Higgins, 1999]:

(1) sliding disk on flat plate with spring restoring mechanism (Eradiquake by RJ Watson)

(2) rolling ball in steel cone (Ball-N-Cone by Tekton)

(3) articulated slider on spherical plate (Friction Pendulum System, FPS by Earthquake Protection Systems)

(4) pot bearing and slider, shock transmission unit, and bi-directional elastoplastic springs (Slider Bearing by FIP Energy Absorption Systems)

(5) elastomeric bearings with lead core (LRB by Dynamic Isolation Systems)

(6) elastomeric bearings with lead core (LRB by Skellerup Base Isolation)

(7) elastomeric bearings with high damping rubber (HDR by Scougal Rubber)

(8) elastomeric bearings (Steel Rubber Bearings, SRB by Tekton)

Each manufacturer supplied five bearings for testing with three different load capacities: $667 \mathrm{kN}, 2225 \mathrm{kN}$, and $3335 \mathrm{kN}$ (150 kip, $500 \mathrm{kip}$, and $750 \mathrm{kip}$ ). The maximum applied shear displacements were $150 \mathrm{~mm}, 225 \mathrm{~mm}$, and $300 \mathrm{~mm}$ (6 in, $9 \mathrm{in}$, and $12 \mathrm{in}$ ), respectively. Cyclic tests were conducted to determine the basic properties of each device (stiffness and energy dissipation), and variations with compressive load, frequency dependence, resistance to fatigue and wear, environmental susceptibilities, temperature dependence and ultimate limit states. Detailed results are reported in a set of eight reports (one for each device). Summaries have also been published [Ghasemi and Higgins, 1999] and [Ghasemi, 1999]. Comparative assessment of relative performance is, however, left to the reader.

A comparable program for passive energy dissipators is currently in progress at HITEC, together with an extension to the isolator program, which involves a second set of isolators.

\subsection{Design Aids, Guidelines, Specifications and Codes}

One sign of a maturing technology is the appearance of design aids, text books, guidelines, manuals, specifications and codes, that assist implement and govern the use of the technology in the real-world.

Early texts by Soong [1990] and Skinner et al [1993] have been joined more recently by Kelly [1996], Soong and Dargush [1997], Constantinou, Soong and Dargush [1998], and Naeim and Kelly [1999]. It is also noted that Priestley, Seible and Calvi [1996] include a chapter on isolation and energy dissipation in their text on the 
seismic design and retrofit of bridges. The growing number of such publications is encouraging but, even so, the total number is very small and is an ongoing impediment to the wider use of these technologies.

Generic software for isolation design is also available and short courses for the professions (architects and engineers) are becoming more common. Building and bridge codes around the world now acknowledge the existence of passive control as an acceptable alternative to conventional design, but the degree to which they do so, varies considerably.

For example in Japan, the application of isolation to bridge structures is limited by the spectral shapes in the Japanese bridge codes. They are such that very long period-shifts would be necessary to achieve any significant force reduction and thus flexibility and period-shifting is not attempted. Instead isolators are simply used to dampen response and to redistribute lateral loads more favorably between the substructures. Furthermore, the isolators are only effective in the longitudinal direction because side restraints are mounted at all pier caps to prevent transverse displacements occurring in the isolators. This adaptation of seismic isolation is called menshin design in Japan and is described in the Manual of Menshin Design Method for Highway Bridges [Ministry of Construction, 1992] and by Kawashima and Unjoh, [1994].

Few seismic codes make specific provision for seismic isolation and/or passive energy dissipation, but examples are to be found in New Zealand, Europe, and the United States. Of these, the 1997 edition of the Uniform Building Code in the United States is probably the most detailed [ICBO, 1997].

Intended for new buildings, the underlying philosophy of this code is that isolated buildings are expected to outperform conventional construction in moderate and large earthquakes [Naeim and Kelly, 1999]. The intent of the code is therefore not to reduce the cost of the structure, but to control damage to the frame and contents by taking advantage of the force reductions due to period-shifting and added damping. Developed from SEAONC's 'Tentative Seismic Isolation Design Requirements' [1986], the current procedures have become considerably more complex and, in some cases, more onerous, than the 1986 document.

On the other hand, there are no code requirements for existing buildings, but Chapter 9 of the NEHRP Guidelines for the Rehabilitation of Buildings [FEMA, 1997a] specifically addresses the application of both isolation and energy dissipation to existing buildings. Whereas the isolation requirements closely follow the UBC 1997 provisions, the energy dissipation requirements are of particular interest because 'they constitute the first comprehensive suite of such procedures ever published' [Sec 9.3.1, FEMA, 1997b]. Various linear and nonlinear analysis procedures are recommended but, consistent with practice for conventional design and rehabilitation, nonlinear static procedures are preferred. Capacity and demand spectra are modified to include the beneficial effect of energy dissipation systems (EDS), as illustrated in Figure 11.

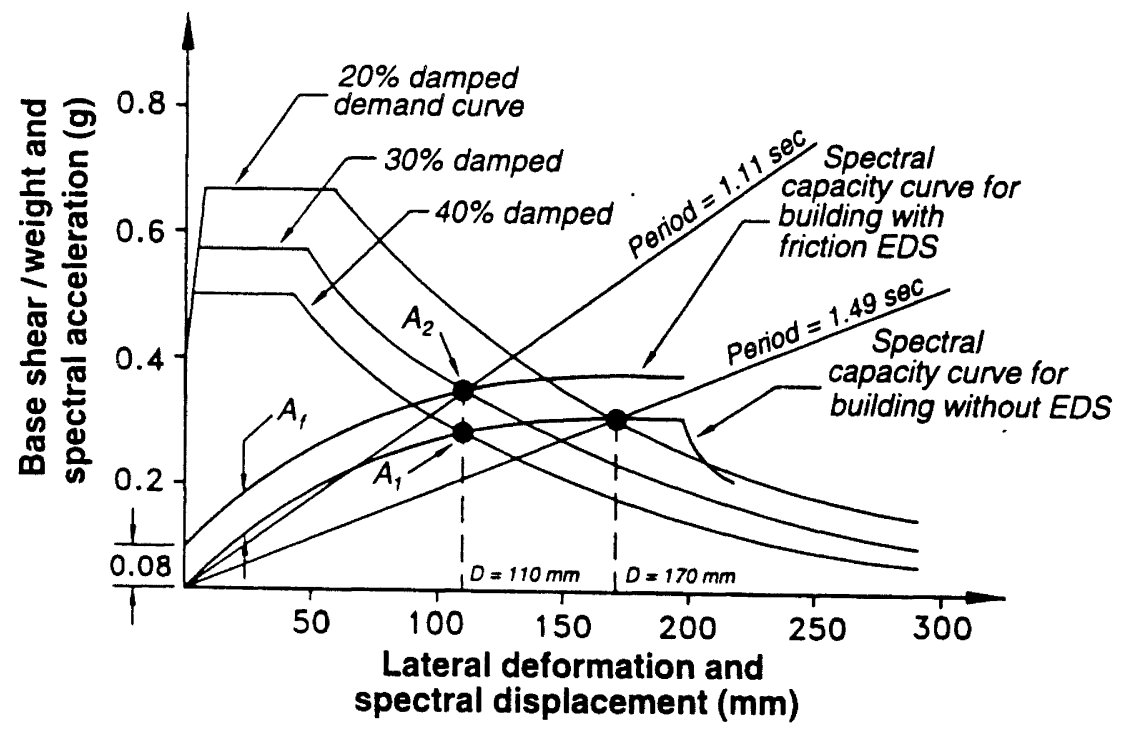

Figure 11: Spectral capacity and demand curves for rehabilitated one-story building [FEMA, 1997b] 
Similar activity is also reported in the United States regarding isolation requirements for new highway bridges. The 1991 Guide Specification for Seismic Isolation Design, published by the American Association of State Highway and Transportation Officials (AASHTO), was completely revised during the period 1995-97 and recently released as AASHTO [1999]. The new specification extends the previous provisions to explicitly include sliding systems and makes a number of changes to the methods of analysis

and allowable force reduction factors. But the most significant change is the introduction of system property modification factors, called $\lambda$-factors. These factors are intended to account for the effects of temperature, aging, wear, contamination and other effects encountered by bridge isolators in their exposed locations. $\lambda$-factors are given for both elastomeric and sliding isolators. For example, aging $\lambda$-factors vary from 1.1 to 1.3 for standard natural rubbers, and from 1.1 to 1.5 for unlubricated PTFE sliding bearings (sealed and unsealed). Factors for other rubber compounds and sliding components are also specified.

A manual for the retrofit of existing highway bridges, using seismic isolation and energy dissipation, is currently under development. The project is sponsored by FHWA and is due for completion in 2001 .

\section{FUTURE TRENDS}

The success enjoyed today by passive control must be tempered by the relatively small number of such structures that have been subjected to moderate and/or major earthquakes. Just as with conventional construction, large earthquakes teach their own lessons despite the care undertaken by the designer in mathematical modeling and exhaustive production testing. It must be expected that the first large event that occurs in close proximity to a passively-protected structure will bring a new set of lessons and surprises. To avoid possible embarrassment, improved ground motion modeling is required, the issue of damping must be resolved, performance criteria must be defined and isolator response optimized. It seems that the future of passive control is in the semi-active field where the intelligent isolator will one-day emerge and combine the advantages of passive systems (capacity and reliability) with those of active systems (optimal wide-band response).

It is also expected that with experience, design codes will become less conservative and easier to implement. In time, the disincentives to use passively protected systems, imposed by complex codes and exhaustive testing requirements, will disappear.

\section{ACKNOWLEDGEMENTS}

Many people contributed to this paper, some inadvertently. I acknowledge their contribution, which in several cases represents a lifetime of work. For their intellect, insight, and willingness to share their dreams, I am most grateful.

\section{REFERENCES}

AASHTO, 1991 and 1999, "Guide specification for the seismic isolation design of highway bridges", American Association State Highway and Transportation Officials, Washington DC.

Amin, N., Mokha, A. and Fatehi, H., 1993, "Seismic isolation retrofit of the US Court of Appeals building", Proc. Sem. Seismic Isolation, Passive Energy Dissipation and Active Control' Applied Technology Council, Report ATC 17-1, pp 185-195.

Buckle, I.G. and Liu, H., 1993, "Stability of elastomeric seismic isolation systems" Proc. Sem. Seismic Isolation, Passive Energy Dissipation and Active Control, Applied Technology Council, Report ATC17-1, pp293-305.

Buckle, I.G. and Mayes, R.L., 1990, "Seismic isolation: history, application and performance - a world view", Earthquake Spectra, Vol 6, No 2, pp161-201.

Constantinou, M.C., Soong, T.T. and Dargush, G.F., 1998, "Passive energy dissipation systems for structural design and retrofit", Monograph, Multidisciplinary Center for Earthquake Engineering Research, University at Buffalo, New York, 299pp.

de Montalk, R.W., 1932, "Shock absorbing or minimizing means for buildings", US Patent 1,847,820, (NZ Patent granted 1929). 
FEMA, 1997a, "NEHRP guidelines for the seismic rehabilitation of buildings", Federal Emergency Management Agency, Report FEMA-273, Washington DC.

FEMA, 1997b, "NEHRP commentary on the guidelines for the seismic rehabilitation of buildings", Federal Emergency Management Agency, Report FEMA-274, Washington DC.

Ghasemi, H., 1999, “Seismic protection of bridges”, Public Roads, US Department of Transportation, Jan/Feb., Washington DC.

Ghasemi, H. and Higgins, M.S., 1999, "Sizing up seismic bearings", Civil Engineering, American Society of Civil Engineers, July, pp55-59.

Hall, J.F. and Ryan, K.L., [to appear], "Isolated buildings and the 1997 UBC near-source factors", submitted for publication 1999.

Housner G.W., et al, 1997, "Structural control: past, present, and future", American Society of Civil Engineers, J. Eng. Mech., Vol 123, No 9, Special Issue, pp 897-971

ICBO, 1997, "Earthquake regulations for seismic-isolated structures", App Chap 16, Uniform Building Code, International Conference of Building Officials, Whittier CA.

Kawashima, K. and Unjoh, S., 1994, "Menshin design of highway bridges in Japan", Proc. Third US-Japan Workshop Earthquake Protective Systems, Buckle and Friedland (Eds), Technical Report 94-0009, National Center for Earthquake Engineering Research, University at Buffalo, NY.

Kelly, J.M., 1999, “The role of damping in seismic isolation”, Earthquake Engng. Struc. Dyn., Vol 28, No 1, pp 3-20.

Koh, C.G. and Kelly, J.M., 1988, "A simple mechanical model for elastomeric bearings used in base isolation", Int. J. Mech. Sci., Vol 30, No 12, pp933-943.

Lee, G.C., Tong, M. and Wu, Y.H., [to appear], "Some design issues for building seismic retrofit using energy dissipation devices", submitted for publication 1999.

Ministry of Construction, 1992, "Manual of menshin design method for highway bridges", Civil Engineering Research Center (in Japanese).

Naeim, F. and Kelly, J.M., 1999, "Design of seismic isolated structures”, John Wiley, 289pp.

Nagarajaiah, S. and Ferrell, K., 1999, "Stability of elastomeric seismic isolation bearings", American Society of Civil Engineers, J. Struc. Eng., Vol 125, No 9, pp 946-954.

Priestley, M.J.N., Seible, F. and Calvi, G.M.,1996, "Seismic design and retrofit of bridges", John Wiley, 1996.

Olariu, I., 1994, "Passive control and base isolation: state-of-the-art lecture" Proc. 10th European Conf.

Earthquake Eng., Duma (Ed), Balkema, Rotterdam, pp703-713.

Robinson, W.H., [1999], "Products", Web page, www.robinson-seismic.co.nz/products.

SEAONC, 1986, "Tentative seismic isolation design requirements" (The Yellow Book), Structural Engineers Association of Northern California, San Francisco.

Skinner, R.I., Robinson, W.H., and McVerry, G.H., 1993, “An introduction to seismic isolation”, John Wiley $354 \mathrm{pp}$.

Soong, T.T., 1990, "Active structural control", Longman Group, 194pp.

Soong, T.T. and Dargush, G.F., 1997, "Passive energy dissipation systems in structural engineering", John Wiley. 